れている (中野ら，未発表）。トが聞き取れないアワノ メイガの超音波のような音を利用した交信は, ガ類やそ の他の昆虫だけでなく, 様々な動物で見いだされること が期待される。

1) L. A. Miller \& A. Surlykke : BioScience, 51, 570 (2001).

2) W. E. Conner : J. Exp. Biol., 202, 1711 (1999).
3) R. Nakano et al. : Naturwissenschaften, 93, 292 (2006).

4) R. Nakano et al. : Proc. Natl. Acad. Sci. USA, 105, 11812 (2008).

5) R. Nakano et al. : Comm. Integr. Biol., 2, 123 (2009).

6) M. Zuk \& G. R. Kolluru: Q. Rev. Biol., 73, 415 (1998).

(中野 亮, 田付貞洋, 東京大学大学院農学生命科学研 究科)

\title{
A Stressful Episode in Plant Biology Are you a real ABA receptor?-Give me a break !
}

筆者は最近，本誌において「植物の成長を制御するサ イトカイニン情報伝達機構」と題した「解説」を寄稿す る機会をいただいた(Vol. 47, No. 5, 312-322, 2009). この 中で植物ホルモンの受容体に関して紹介した導入部分を 補足する必要が生じたので,「今日の話題」として紹介し たい.「解説」で紹介したように，シロイヌナズナを用い た研究からサイトカイニンやオーキシンを含む主要な植 物ホルモンの受容体が次々と同定された。「解説」では, アブシジン酸 $(\mathrm{ABA})$ の受容体を三量体 $\mathrm{G}$ タンパク質共 役受容体として紹介した (解説の図 1 参照)。これは紆余 曲折を経た $\mathrm{ABA}$ 受容体検索に関する最新報告に基づい たものであった ${ }^{(1)}$. しかしその後, ストレス応答に関与 するホルモンである ABA の受容体同定の経緯に関し て, 植物生理学者にとってはまさにストレスに富んださ らなる曲折が生じたので紹介したい(2).

ABA は 1960 年代に, 種子の休眠や落葉を促進する植 物ホルモンとして発見された. その後, 気孔の開閉, 乾 燥や低温耐性に関わるストレス応答ホルモンとして注目 されて多くの研究が蓄積されてきた，乾燥や低温に対す る応答は作物・穀物などの食糧生産にとって重要な要因 であり, ABA が植物生理学者の注目を集めたことは当 然の成り行きである. その結果として, 主にシロイヌナ ズナを用いた研究から ABA 応答情報伝達経路に関して も多くの知見が蓄積している。しかし, ABA 情報伝達 経路の先頭にあるべき受容体の同定に関しては「語るも 涙」の物語がある.「今日の話題」を提供するためには, その物語を簡単に振り返る必要がある（以下, 図 1 参 照) ${ }^{(3,4)}$.

植物細胞の抽出液から生理的に意味のある結合定数で 特定のホルモンを特異的に結合するタンパク質を分画す ることは容易ではない，たとえばサイトカイニン結合夕 ンパク質の精製の報告は数多くあるが，どれ一つとして
ヒスチジンキナーゼ $(\mathrm{AHK} 2 / 3 / 4)$ には結び付かなかっ た (「解説」の図 1 参照). ABA 受容体の検索も例外では なかった。しかし，2006 年になり ABA を結合する受容 体タンパク質の候補がシロイヌナズナを用いて報告され た ${ }^{(5)}$. 同定されたのは FCA と呼ばれ, 花芽形成時期の制 御機構に興味のある研究者にとっては馴染み深い RNA 結合タンパク質であった. FCA はFY と呼ばれる別の タンパク質との相互作用を介して, 花芽形成の主要な抑 制転写因子である FLC 合成を制御していることが知ら れていた。論文の著者らは, ABA が FCA に直接結合し て FY との協調作用を阻害することを試験管内実験およ び植物体を用いて示した。 ABA が花成時期制御に影響 を与えることを根拠に, ABA が FCA-FY 経路を介して FLC の蓄積を促して花成を遅延させるという機構が提 案された。この報告は, $\mathrm{ABA}$ 受容体の最初の確からし い報告として注目された。 そこで, 早速他の研究者によ り $\mathrm{ABA} の \mathrm{FCA} へ の$ 結合が追試されたが, 残念なこと に再現されなかった ${ }^{(6)}$. 論文の著者らもこれを認め, 当 該論文は撤回されるに至った. FCA の変異株が花成制 御以外の ABA 関連の現象に関しては目立った表現型を 示さないことからも, FCA が ABA 受容体である可能性 は低いと考えられる.

こうして一人の役者が舞台から退場するとほぼ同時 に, 別の役者が登場した。 次なる $\mathrm{ABA}$ 受容体の候補と して，これも有名なクロロフィル合成の中間反応を触媒 するマグネシウムキラターゼ酵素複合体の $\mathrm{H}$ サブユ ニット (GUN5 遺伝子の産物) が報告された ${ }^{(7)}$.この論文 の著者は, ABA のマグネシウムキラターゼへの結合を 示しただけでなく，そのシロイヌナズナ変異株は種子の 休眠や気孔の開閉において ABA 非感受性を示し, 生理 的にも $\mathrm{ABA}$ 受容体の要件を満たしていることを報告し た.しかし，この報告にも疑問の声が多い. クロロフィ 


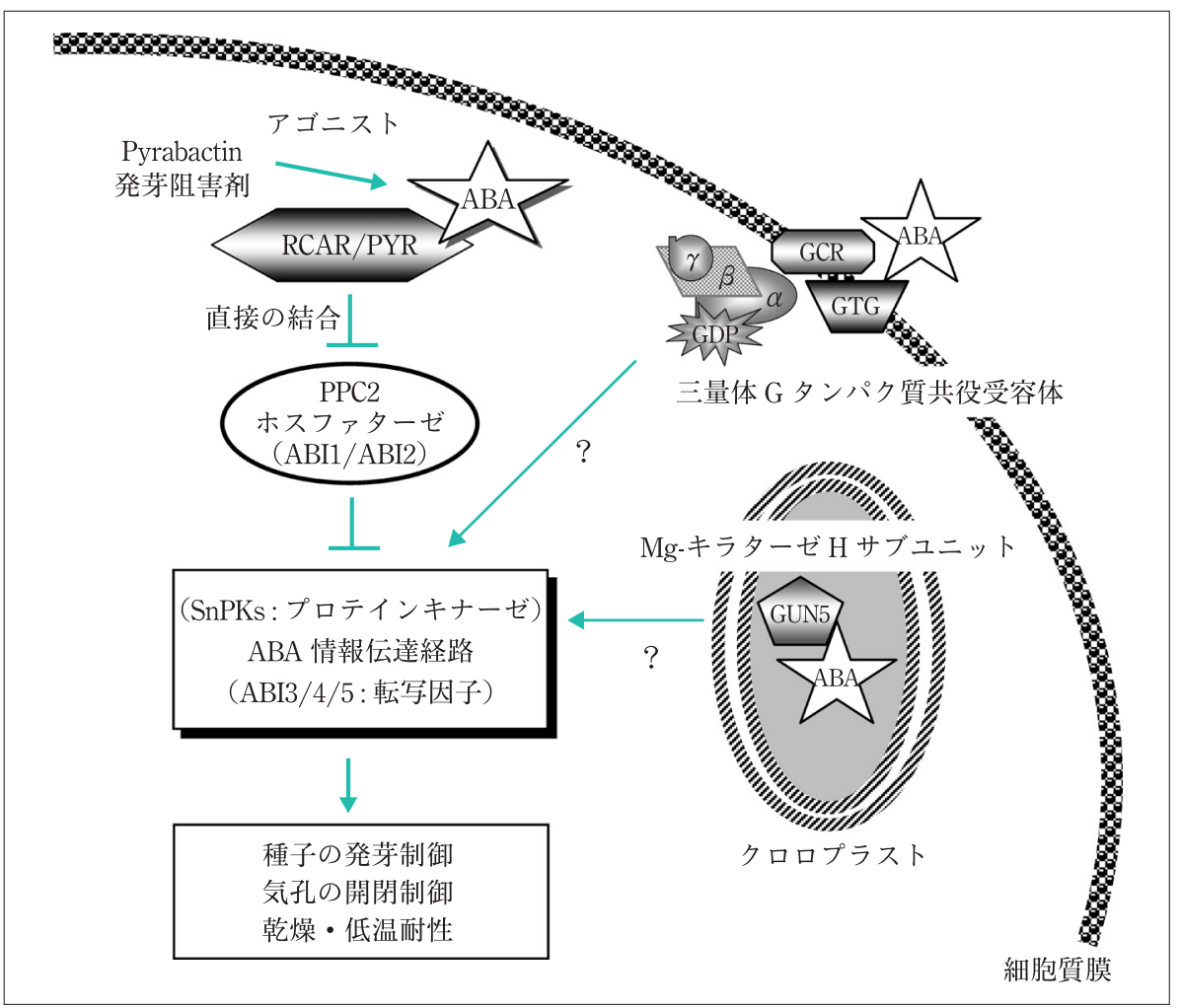

図 1 - ABA 受容体の同定

$\mathrm{ABA}$ 受容体の同定のエピソードに 登場する役者の概要を模式化した が，FCAに関しては削除した（詳 しくは本文参照）。本文中での説明 を省いたが, SnPKsはSNF1ファ ミリーに属する一群のプロテインキ ナーゼであり, ABI1 や ABI2 プロ テインホスファターゼの標的として $\mathrm{ABA}$ 情報伝達経路に組み込まれて いると考えられている（文献 4 参 照).
ル合成という植物にとって必須の役割を担う酵素が，は たして光合成とは直接関係がないと思われる $\mathrm{ABA}$ 応答 における主要な受容体として重要な二役を担うであろう か. また，オオムギのマグネシウムキラターゼ機能損傷 変異株は ABA 応答に関して何ら表現型を示さないとの ことである(2). 総合すると, マグネシウムキラターゼも 主要な $\mathrm{ABA}$ 受容体でないかも知れない.

さて, ホルモンの受容体というと一般には膜局在性夕 ンパク質が候補として考えられる。この点, FCA むマグ ネシウムキラターゼも膜局在性ではない. ABAにも膜 局在性受容体があってもおかしくない。これと関連し て, 膜局在性受容体と共役して働く三量体 G タンパク質 情報伝達経路が ABA 情報伝達系に関与していることが 示唆されている。これらを背景に膜局在性で三量体 G夕 ンパク質と共役しそうなタンパク質がコンピューター検 索により見いだされ，GCR2 と命名されて ABA 受容体 の新たな候補として報告された (図 1 参照) $)^{(8)}$. この論文 によると，GCR2 は試験管内で ABA を結合するだけで なく，その欠損植物変異体は種子の発芽や気孔の開閉試 験において ABA 感受性が低下していることが示され た。しかし，実際 GCR2 はABA を結合しないし，GCR
2 およびその類似タンパク質をコードする遺伝子を含む 多重変異体を作製しても $\mathrm{ABA}$ 関連の明確な表現型を示 さないという反論が報告され，GCR2 が真の ABA 受容 体かどうか疑問が多い(9,10).

こうして ABA 受容体の同定は再び暗礁に乗り上げた かに見えた。しかし，2009 年になり別の三量体 G タンパ ク質共役膜夕ンパク質と思われるものが $\mathrm{ABA}$ 受容体候 補として報告された(1). むちろん, 生化学的な $\mathrm{ABA}$ 結合 実験の結果や，遺伝学による ABA 情報伝達への関与を 示す証拠を揃えた上での報告である.これが「解説」で 取り上げた ABA 受容体であり, GTG1 および GTG2 と 呼ばれる膜夕ンパク質である。しかし，これら GTGの $\mathrm{ABA}$ への親和性の低さや, 実は動物の GTG 類似夕ン パク質はイオンチャネルと考えられていることから，こ れに関しても疑問の余地がある(2).

以上, 4 種類の $\mathrm{ABA}$ 受容体候補に関する報告に関し て概観してきたが，FCA を除いてはその報告が撤回さ れたものはない。したがって，ABA 受容体を確定する にはさらなる議論が必要であり, 論理的には ABA 受容 体が複数ある可能性を捨てることはできない.いずれに しろ， $\mathrm{ABA}$ 情報伝達経路に関わる下流遺伝子群（ABI1 
〜ABI5 など）は遺伝学的に数多く同定されているが, これまで紹介した受容体候補のいずれも既存の ABA 情 報伝達因子と直接の関連をうかがわせるものはなかった (図 1 参照). しかし, ここに至って, 既知の ABA 情報 伝達因子と明確な関連を示す有力な $\mathrm{ABA}$ 受容体候補因 子が新たに報告された。おまけに，ほぼ同じ結論が $2 つ$ の独立した研究グループより同時に報告された ${ }^{(11,12)}$. そ こで,「解説」の補足修正も含めて「今日の話題」として 紹介する必要があると考えた次第である.

現在まで, 遺伝学的に $\mathrm{ABA}$ 情報伝達経路の最上流に 位置付けられている因子は, ABI1 と ABI2 と呼ばれる PPC2 ファミリーに属するプロテインホスファターゼで ある. ABI1/ABI2 は ABA 情報伝達経路の負の調節因 子と考えられている. 今回新たに報告された $\mathrm{ABA}$ 受容 体候補は ABI1/ABI2 と直接相互作用しその酵素活性を 阻害する因子として同定された。同定された因子には既 知の機能ドメインは見あたらないが，アミノ酸配列が似 た（機能の重複すると思われる）タンパク質ファミリー を形成することから，発見した 2 つのグループにより独 立に RCAR および PYR/PYL ファミリー因子と命名さ れた.これら因子は $\mathrm{ABA}$ と結合して $\mathrm{ABI} 1 / \mathrm{ABI} 2$ およ び関連 PPC2 ホスファターゼ (HAB) の活性を阻害する ことで $\mathrm{ABA}$ 情報伝達系を活性化することが報告され た。これらの内容を考えただけでも，ABA 情報伝達機 構の門外漢には今度こそ本物らしく思える（そう願いた い). そこで, 以下その概要を簡単に紹介したい（図 1 参 照).

$\mathrm{Ma}$ らは, ABI1/ABI2 と結合する新規タンパク質ファ ミリーを見いだした ${ }^{(11)}$ 。このファミリーには 14 種類の 相同タンパク質が含まれるが，その中の代表である RCAR1 とRCAR2 に関して詳細に検討し, ABI1/ABI2 単独では ABA の結合能は低いが, RCAR-ABI1/2 複合 体には ABA が強く結合して ABI1/ABI2のホスファ ターゼ活性を阻害することを示した。 また，これらファ ミリータンパク質のすべてでないにしても複数のものが 重複した機能を担っていると考えられる. そこで, 著者 らはRNAi および RCAR1 過剩発現形質転換体の表現 型を解析することで ABA 情報伝達経路への関与を生理 学的に示している.

一方で, Park らはまったく別のアプローチによりほ ぼ同じ結論に達した ${ }^{(12)}$. 彼らは種子の発芽を阻害する合 成化合物 (Pyrabactin) を解析して, それが ABA 情報伝
達経路を標的としていることを見いだした．次いで， Pyrabactin の直接の標的因子を検索するために耐性変 異体を分離解析した（いわゆる今流行の Chemical Genetics である).こうして見いだされた遺伝子はPYR1 と名付けられたが，Maらが同定したのと同じファミ リーの一員であった. 彼らはPYR1 が単独で ABA と強 く結合し, 結果として ABI1/ABI2 や類似の PPC2 ファ ミリーホスファターゼ（HAB1 と命名）と相互作用をし てその活性を阻害することを示した。

両者の主張するABA-PCAR/PYR-ABI1/2 の結合様 式に関しては若干の違いがあるが，いずれにしろ以上の 2 つの報告は相補的であり, 既知の $\mathrm{ABA}$ 情報伝達経路 との整合性もある。一般に植物ホルモン情報伝達経路で は，通常は負の制御因子によりブレーキがかかってお り, ホルモンが受容体と結合してそれが解除されるとい うスキームにもよく符合する（エチレン，オーキシン， ジベレリン経路などがその典型的である）(図 1 参照). こうして全体としては, 今までの中では最も説得力に富 んだ ABA 受容体と思われる。また, Pyrabactinは ABA のアゴニストと考えられる.

以上紹介したように，これまでに趣の違った複数の ABA 受容体が報告されている。しかし，考察したよう に最後の報告を除いては幾つかの疑問点が残っているの が現状である．FCA に至っては撤回されている．いずれ にしろ, 以上紹介した ABA 受容体に関するエピソード はNature の 2 報, Scienceの 3 報, Cell の 1 報を基にし ている.いずれも Impact Factor の高さを競う超一流 の雑誌である.もちろん, ABA 受容体の発見が植物生 理学分野にとってインパクトの高い課題であることは認 めるし, 時と場所 (生育時期や器官・組織) の違いによ り働く複数の ABA 受容体が存在してもおかしくない. しかし, ABA 情報伝達系の門外漢には少々困惑せずに はおられない混乱が起こるのはなぜだろう。 その理由を ここで詮索するつもりはないが，オンライン化されイン パクトと速報性を競う多くの専門誌に支えられて細分 化・多様化・先端化が進む現代生命科学一般に潜む混乱 の一側面かも知れない. いずれにしろ，このエピソード を参考に自らの研究スタイルをかえりみることが肝要か と思う（時として見えるものが見えるのではなく，見た いと願うものが見えることがある). ABI1/ABI2 ホス ファターゼ阻害因子としての RCAR/PYR ファミリー 因子は真の $\mathrm{ABA}$ 受容体であろうか？ 新しい報告(12) 
では, ABA 情報伝達研究のうるさ方である P. McCourt （総説 3 の著者）も名を連礼ていることから, 今度こそ本 物であることを願う。

最後に，この話題の文脈は Science の E. Pennisi の論 評に負うところが多いことを明記したい(2).

1) S. Pandey et al. : Cell, 136, 136 (2009).

2) E. Pennisi : Science, 324, 1012 (2009).

3) P. McCourt et al. : Curr. Opin. Plant Biol., 11, 474 (2008).

4) T. Hirayama et al. : Trends Plant Sci., 12, 343 (2007).
5) F. A. Razem et al. : Nature, 439, 290 (2006).

6) J. M. Risk et al.; Nature, 456, E5 (2008).

7) Y. Y. Shen et al. : Nature, 443, 823 (2006).

8) X. Liu et al. : Science, 315, 1712 (2007).

9) Y. Gao et al. : Plant J., 52, 1001 (2007).

10) J. Guo et al. : PLo ONE, 3, e2982 (2008).

11) Y. Ma et al. : Science, 324, 1064 (2009).

12) S.-Y. Park et al. : Science, 324, 1068 (2009).

(水野 猛, 山篠貴史, 名古屋大学大学院生命農学研究 科)

\section{DNA は細胞内で三重らせん・四重らせん構造を形成しているか? DNA の多様な高次構造を安定化する細胞内環境因子に注目}

DNA の標準構造である二重らせんは，シンプルで美 しい. また，ワトソンークリック型塩基対からなる二重ら せん構造は遺伝情報の保持と伝搬のためにきわめて合理 的でもある。しかし，DNA は塩基配列と周辺環境に依 存して, 多様な非標準構造を形成し, 遺伝子発現の制御 などに重要な役割を担うことも明らかになりつつある。

特に，二重らせん以外の構造を形成する可能性が高いと 考えられているのが，グアニンに富んだ DNA 鎖（G 鎖） とその相補鎖であるシトシンに富んだ鎖 ( $\mathrm{C}$ 鎖)，および アデニンとグアニンに富んだ鎖（プリン鎖）とその相補 鎖であるチミンやシトシンに富んだ鎖（ピリミジン鎖） である. G 鎖と C 鎖はそれぞれが四重らせん構造を，プ リン鎖とピリミジン鎖は三重らせん構造を形成できる. たとえば，G 鎖はヒトゲノム中の 30 万個所以上に存在 することが知られている(1). 特に興味深いことに， G 鎖 は, $c-m y c$ など様々な疾患に関与する遺伝子の開始領域 の直前に局在することも示されている．そのため， G 鎖 と $\mathrm{C}$ 鎖, またプリン鎖とピリミジン鎖の形成できる非標 準的な高次構造が注目を集めている.

多様な高次構造を形成する DNA の代表が染色体の末 端に位置するテロメアである（図 1-A）。テロメア DNA は，二重らせん構造を形成すると考えられている領域と 一本鎖状態の突出領域からなる．前者は， G 鎖とその相 補鎖の C 鎖から形成される. 後者の突出領域は, 数十か ら数百塩基の $\mathrm{G}$ 鎖のみで構成されている（相補的な $\mathrm{C}$ 鎖は存在しない).この突出領域は, 四重らせん構造を形 成できる，四重らせん構造では，4つのグアニン塩基が 環状となりフーグスティーン塩基対を形成し G-カル テットと呼ばれる平面構造を形成する。この G-カル
テットどうしがスタッキング相互作用を形成し，さらに その中心の空孔に金属イオンが配位することで，四重ら せん構造が形成される（図1-B)。この四重らせん構造 は，細胞の寿命やがん化に関与すると考えられている. このように重要な DNA 四重らせん構造とその熱力学的 安定性に及ぼす細胞内の環境因子（後述）の効果を定量 的に解析することで, 細胞内におけるテロメア DNA の 高次構造が検討されている.

細胞内におけるテロメア DNA の高次構造に関する研 究の端緒となったのが, 2000 年代前半の筆者らによる報 告である. 生体分子が存在する細胞内には, $75 \sim 150 \mathrm{~g} / l$ の RNA， 200〜300 g/l のタンパク質が存在している. これらの分子が占める体積は細胞全体の 20〜 40\%に達 し, 分子が混み合った状況をつくり出す。このように, 分子が非常に混み合うことを分子クラウディングと呼 ぶ. 一方, 通常の生化学的な実験における標的分子の濃 度は, $1 \mathrm{~g} / l$ 以下である.すなわち, 細胞内と試験管内実 験で最も大きく異なる環境因子が分子クラウディングで あるといえる，そこで筆者らは，細胞を模倣した分子ク ラウディング環境下における $\mathrm{G}$ 鎖からなる突出領域の モデル DNA として, 繊毛虫の一種である Oxytricha 由 来のテロメア DNA， $\mathrm{d}\left(\mathrm{G}_{4} \mathrm{~T}_{4} \mathrm{G}_{4}\right)$ を用いた。希薄溶液中 で, $\mathrm{d}\left(\mathrm{G}_{4} \mathrm{~T}_{4} \mathrm{G}_{4}\right)$ は 2 分子が会合して逆平行型の四重らせ ん構造を形成することが知られている。しかし，このテ ロメア DNA の構造を PEG（ポリエチレングリコール） で誘起した分子クラウディング環境下で測定したとこ ろ, 平行型の四重らせん構造を形成することが示され た (2). すなわち, 分子クラウディングは, テロメア DNA の構造を逆平行型から平行型四重らせん構造へとスイッ 